\title{
The Turkish presidential elections of 24 June 2018
}

\author{
Berk Esen ${ }^{\mathrm{a}}$ and Şebnem Yardimci-Geyikçi ${ }^{\mathrm{b}}$
}

a Department of International Relations, Bilkent University, Ankara, Turkey; ${ }^{\text {b Department of }}$ Political Science and Public Administration, Hacettepe University, Ankara, Turkey

\section{Introduction}

On 24 June 2018 Turkish voters headed to the polls to elect a new president and parliament after President Recep Tayyip Erdoğan's decision to call for snap elections eighteen months earlier than scheduled. The election was noteworthy for several reasons. First, the electoral campaign took place under emergency law that was initially issued after the failed 2016 putsch. Following the coup attempt, the government carried out a widespread purge of its opponents in the public sector, curtailed political space for dissent, and subsequently consolidated its hold on power, thus tilting the already uneven playing field. Furthermore, this was the first election held after the 2017 constitutional referendum that created an executive presidency with limited checks and balances. Allied with the opposition leader Devlet Bahçeli, President Recep Tayyip Erdoğan rationalized his decision to call for snap elections by suggesting that the country needed to inaugurate the new system to ensure effective decision-making during hard times. Indeed, there was worry among pundits that the Turkish economy was heading for an economic crisis, as evidenced by the rising levels of unemployment and inflation rate, not to mention the weak national currency. As such, the timing of snap elections was chosen with the intention of hindering the opposition's ability to cooperate, particularly when socio-economic worries, as well as the large number of Syrian migrants in the country, had begun to erode the government's popularity.

Throughout the campaign, the opposition candidates faced an uneven playing field against the incumbent due to the excessive coverage of the latter in national media and his unfair access to public and private resources. While Erdoğan was the clear frontrunner, he defied the opinion polls by winning the presidency in the first round with 52.6 per cent of the vote. We contend that in addition to benefiting from the uneven playing field that has been a feature of Turkey's competitive authoritarian regime (Esen \& Gumuscu, 2016), Erdoğan owes this victory to his lasting popularity and growing hegemony over the 
political system. As the country's undisputed leader, Erdoğan still enjoys strong support among the conservative voters, many of whom attribute their economic achievements under the AKP rule to him. Erdogan consolidated this electoral base by portraying the election as a contest between his nationalistconservative camp and the rest. In particular, he resorted to media sanctions and intimidation to sideline credible rivals from the conservative camp, while eliminating the popular pro-Kurdish candidate through imprisonment. It should be also noted that the ruling party did not hesitate to resort to extrajudicial methods, such as vote rigging, ballot stuffing, and voter intimidation. Although these methods do not account for Erdoğan's victory in the end, they demonstrate that meaningful electoral competition in Turkey is becoming exceedingly difficult. With his victory Erdoğan has become the head of the executive branch and will directly govern the country through his cabinet.

\section{Presidential candidates}

The front runner of the race was the current president Erdoğan, who was nominated by his ruling Justice and Development Party (Adalet ve Kalkınma Partisi, AKP) and the ultra-nationalist Nationalist Action Party (Milliyetçi Hareket Partisi, MHP) that had supported Erdoğan on numerous critical issues throughout the last two years. By contrast, the opposition camp failed to unite behind a single candidate. Initially, the main opposition Republican People's Party (Cumhuriyet Halk Partisi, CHP) leader Kemal Kılıçdaroğlu, in coordination with the Islamist Felicity Party (Saadet Partisi, SP) leader Temel Karamollaoğlu, reportedly tried to nominate the former president and AKP founder Abdullah Gül as the opposition's candidate and even received the tacit consent of the left-wing Kurdish nationalist Peoples' Democracy Party (Halkların Demokrasi Partisi, HDP) leadership. According to some political circles in Turkey, Gül was the only candidate who could defeat Erdoğan by drawing support from both conservative and moderate voters. Once Gül's candidacy became a strong possibility, however, Erdoğan's spokesperson İbrahin Kalın and the Chief of the General Staff Hulusi Akar visited Gül, allegedly to dissuade him from entering the race. The Gül plan ultimately collapsed as a result of resistance from the CHP rank and file members and Good Party (iYi) leader Meral Akşener, who refused to pull back her candidacy. In the end, each of these parties entered the election with their own candidate.

After weeks of speculation, CHP, the main opposition party, nominated Muharrem Ince, an experienced and sharp-tongued parliamentarian, who twice ran for the party's chairmanship against Kılıçdaroğlu. This choice was widely welcomed by CHP cadres who opposed Gül's candidacy and were relieved to have a well-known candidate from the party's ranks. Founded by ex-MHP members, the newly established lyi Party nominated its leader Meral 
Akşener, a former interior minister and a popular figure in nationalist circles. Similarly, SP declared its popular leader Temel Karamollaoğlu, who has been a staunch critic of AKP's policies, as its candidate. The HDP's candidate was Selahattin Demirtaş, the imprisoned former co-chair of the party and a longtime critic of Erdoğan. Lastly, Vatan Partisi nominated its chairman Doğu Perinçek who is known for his ultra neo-nationalist views.

\section{Electoral campaign: Vibrant opposition against the exhausted incumbent}

Muharrem İnce, who ran a high-spirited campaign that emphasized a nonpartisan image, was arguably the biggest surprise of the presidential race. In less than two months, Ince organized 107 packing rallies in 75 cities across the country, even visiting provinces where the CHP local chapters are weak. Although his rallies were not covered by the pro-government media, his live TV appearances broke audience records and turned him into a social media craze. In his campaign platform, Ince promised to reintroduce the parliamentary system and reunify Turkey without discriminating against any ethnic or religious groups. Coming from a traditional family in the countryside, Ince tried to popularize the Kemalist agenda in a down-to-earth manner, using lines from comedies to criticize Erdoğan without feeding into his polarizing discourse. When Erdoğan called İnce a wretched person (gariban), İnce quickly assumed this ascribed identity to self-identify with the poor and accused Erdoğan of building a lavish palace while ignoring the disadvantaged segments of society. Ince criticized Erdoğan for the current economic downturn, which he attributed to the AKP government's wasteful public spending, reckless foreign policy, and vast corruption. By contrast, he pledged to endorse Turkey's traditional foreign policy and allocate more resources for social assistance, health, and education, albeit without elaborating on policy details. Breaking with the CHP's dominant nationalist rhetoric, Ince also visited pro-Kurdish leader Selahattin Demirtaş in prison and subsequently declared his support for Kurdish instruction (one of HDP's key demands) at schools. Such moves generated some excitement among Kurdish voters, who were alienated by Erdoğan's recent alliance with the MHP and his hardliner rhetoric in the Kurdish question.

Meanwhile, the IYi Party built an innovative electoral campaign based on the professional use of online tools, using the slogan 'Turkey will be good.' The Iyi Party was formed after the 2017 referendum by moderate MHP cadres, who initially broke ranks with Bahçeli over his decision to support Erdoğan. Led by Meral Akşener, the party tried to dispel its image as a splinter party of the MHP by reaching out to new constituencies. The party elites saw Akşener's candidacy as a cornerstone of this political strategy. Keeping in mind her popularity in the nationalist movement and political experience, many pundits indeed thought that she will be a serious challenger to Erdoğan. Similar to İnce, Akşener 
pledged to return to parliamentary rule with a new constitution. Called by her supporters as the Turkish 'she-wolf', however, her Achilles' heel was her inadequacy to appeal to Kurdish voters. In addition to Akşener, Erdoğan also faced opposition from the ranks of the Islamist political movement. The Felicity Party (Saadet Partisi, SP), the successor party of Necmettin Erbakan's National Outlook movement, nominated Temel Karamollaoğlu, the party's chairman. At a time of intense polarization, his candidacy provided an alternative option for the conservative electorate. An engineer trained at Manchester University, Karamollaoğlu ran a modern campaign to appeal to young conservative voters, who had become disillusioned by Erdoğan's autocratic rule in recent years. In particular, he accused Erdoğan and his government of pushing Turkey into a systemic crisis with major political and socio-economic implications. Finally, the HDP nominated its former chairman Selahattin Demirtaş, who performed strongly in the 2014 presidential elections when he obtained 9.78 per cent of the entire vote. Imprisoned over terrorism charges since 2016, Demirtas campaigned from jail through his lawyers who disseminated his messages using social media. Although there was still considerable sympathy towards Demirtaş among his party base, his incarceration prevented him from running an active campaign to reach out to new voters and thus severely limited his electoral appeal this time around.

As a whole, the opposition candidates proposed a common vision of returning to a parliamentary system in which basic rights and freedoms would be protected, rule of law guaranteed, and one-man rule abolished. Accordingly, the leaders of CHP, IYI Party and SP pledged to introduce constitutional amendments in parliament after the election to reverse AKP's authoritarian policies. Unlike previous elections, the opposition appeared strong and acted in a concerted fashion to defeat Erdoğan. Moreover, the emergence of popular right-wing presidential candidates gave many opposition voters hope that Erdoğan's constituency might fragment in this election. This view was further strengthened by opinion polls that predicted that the elections would go into a second round.

As a result, Erdoğan did not look invincible during the electoral campaign. Coming across as tired and frustrated, Erdoğan committed major political gaffes in the campaign, such as advising only those with money to use the third bridge over the Bosporus or handing over to the opposition the motto 'Enough' by saying that 'if, one day, our nation says enough (tamam), then we will move to the side'. In sharp contrast with his energetic campaigns in the past, Erdoğan organized only 32 rallies during this election cycle. Moreover, Erdoğan had only few tangible projects to offer to his electorate after being in power for 16 years. His campaign merely included non-sensational promises such as Kanal İstanbul - an extremely costly project that would foresee the creation of a $45 \mathrm{~km}$ channel linking the Black and Marmara seas west of İstanbul to provide an alternative to the Bosporus Strait - and the opening of national 
coffee-houses (millet kiraathaneleri). across the country which would offer free tea and cake to Turkish citizens.

Meanwhile, similar to the previous elections, the 2018 presidential election campaign was plagued by a playing field that was tilted in favor of Erdoğan and his ruling party. As the sitting president, Erdoğan financed many of his campaign trips from the public budget and obtained open support from numerous public officials in violation of the law (OSCE, 2018, p. 15-16). In contrast, the opposition candidates campaigned with only limited access to private and public resources, not to mention the national media. Due to heavy government pressure on the national media, Erdoğan and his party received favorable and extensive coverage, while opposition candidates were ignored for the most part. Media sanctions were especially harmful to Demirtaş, who could not campaign due to his imprisonment. This unfair coverage was particularly apparent in the case of the public broadcaster, Turkish Radio and Television Corporation (Türkiye Radyo ve Televizyon Kurumu, TRT), which allocated the majority of its news hours to Erdoğan (65 per cent), leaving 9 percent for Akşener and no air time for Demirtaş. Moreover, under emergency rule, activists from opposition parties were on many occasions monitored and harassed by both vigilantes and public officials alike.

\section{What explains Erdoğan's success after 16 years of rule?}

With 26.330 .823 ballots cast under his name, Erdoğan obtained 52.59 per cent of the vote and carried 63 provinces. This was slightly better than his performance of 51.7 per cent in the 2014 presidential elections. In particular, Erdoğan enjoyed substantial backing across the Anatolian heartland, polling over 70 per cent in most of the large provinces. Supported by the main opposition CHP, Ince received 30.64 per cent of the votes and carried 8 provinces - except for Tunceli, all located in Thrace (Edirne, Kırklareli, and Tekirdağ) and Aegean coastal areas (Çanakkale, İzmir, Aydın, and Muğla). İnce outperformed the CHP by nearly 8 per cent and received more votes than his party in the parliamentary elections in all provinces. It is apparent that he reached beyond CHP constituencies to attract votes from both the lyi Parti and HDP. Conversely, the core of Demirtaş's vote $(8.40$ per cent) was located primarily in 10 provinces in Eastern and Southeastern Anatolia, all of which he also carried in 2014. Demirtaş also polled relatively well in big cities with high number of Kurdish migrants such as Mersin (11.9 per cent), Adana (9.3 per cent), İstanbul ( 7.2 per cent), and İzmir ( 6 per cent) while the other presidential candidates failed to top the poll in any province. Meral Akşener, whose party entered into parliament for the first time, fell short of expectations with only 7.29 per cent of the vote. Once touted as the opposition's most popular candidate, Akşener's campaign was outshone by Muharrem Ince who successfully appealed to the nationalist, secular voters that she initially 
targeted. Meanwhile, Karamollaoğlu garnered a dismal 0.89 per cent, failing to gain much support from Erdoğan's supporters.

Given Erdoğan's lackluster campaign, not to mention the excitement generated in the opposition camp by İnce's performance, many commentators were surprised by this result. Although there might be a plethora of factors behind Erdoğan's success, besides the unfair nature of elections, two stand out. First of all, Erdoğan's popularity among the mass electorate was underestimated. Erdoğan is still conceived by many to be a charismatic and persuasive leader who managed to defend Turkey against internal and external enemies. This view was only reinforced after the July 2016 coup attempt when Erdoğan convinced the masses that he is the saviour of state. Accordingly, he succeeded in linking the Turkish state's destiny with that of his own in the eyes of his electorate. This image was further strengthened when the MHP allied with the AKP to introduce constitutional amendments that handed extraordinary powers to the president. Furthermore, the incumbent party and Erdoğan constantly emphasized what they had achieved in the last sixteen years and portrayed those achievements as a guarantee of what they would accomplish in the future. Ruling the country for the last 16 years, Erdoğan managed to appear considerably more credible than the opposition which lacks government experience. In this respect, the election was an extension of the 2017 referendum in that Erdoğan solidified his place as the natural leader for the nationalist-conservative constituency.

Secondly, although he looked less able to frame the entire public debate like in the past, he succeeded in designing the terms of the presidential race. Throughout the campaign, Erdoğan tried to portray the election as a contest between Ince and himself, thereby sidelining other candidates who were more likely to draw support from AKP voters. As such, he turned the first round of the elections into a second round. For instance, while Akşener, Karamollaoğlu, and Demirtaş were absent from the airwaves, İnce was invited frequently to make appearances at private media outlets such as NTV and CNN Turk. According to the OSCE's election report, Erdoğan was allocated 33.7 per cent of air time by public TRT 1 and private A Haber, CNN Turk, and Show TV as opposed to 18.2 and 1.2 per cent for Ince and Akşener, respectively. Many thought that his plan would backfire since İnce performed exceptionally well in TV interviews; however, the final results demonstrate that the promotion of Ince played straight into the hands of Erdoğan, as the race seemed to be between the left (Ince) and the right (Erdoğan). Therefore, the nationalist-conservative voters, who constitute a clear majority in the Turkish electorate and may have contemplated voting for another candidate in the first round, consolidated behind Erdoğan. Accordingly, this way of presenting elections also made the campaign promises secondary, as something bigger was at stake, i.e., the historical gains of the conservative movement under Erdoğan's AKP. 
It has to be also noted that there had been serious allegations of electoral irregularities and ballot stuffing in both the presidential and parliamentary elections. Using statistical election forensics, Klimek, Jiménez, Hidalgo, Hinteregger, and Thurner (2018) claim ballot stuffing to have affected the results in as much as 15 per cent of the polling stations. Ballot stuffing as well as election day violations had mostly been reported in Southeastern and Eastern Turkey, where the AKP and the MHP alliance made surprising gains. While these irregularities do not account for Erdoğan's victory, they certainly played role in preventing the occurrence of a second round, thereby alleviating the opposition's prospects.

\section{Conclusion}

Erdoğan's victory removed the final obstacle against his plan of establishing a super-presidential system with very limited checks and balances. It is clear that Erdoğan now enjoys a far stronger role in shaping government policy than his predecessors ever did in the multi-party era. We can now expect to see a complete overhaul of the state apparatus in accordance with his goal to impose his personal control. Immediately after his victory, Erdoğan indeed moved to redesign several cabinet ministries through presidential decrees, formed a loyal cabinet, and set up executive councils to oversee state functions. Moreover, with the abolition of the Prime Ministry (Başbakanlık), numerous state agencies such as the Chief of General Staff (Genelkurmay Başkanlığı), The Directorate of Religious Affairs (Diyanet Işleri), State Archives, and the National Security Council came under the control of the Presidency (Cumhurbaşkanlığı). However, after more than a century-long parliamentary system, the public bureaucracy may not be ready for such a radical transformation. Inefficiencies in state institutions and tacit resistance among civil servants might force the state bureaucracy to emerge as a potentially powerful veto player, particularly in the event of an economic downturn. Another potential obstacle for Erdoğan may be the parliament where his AKP no longer commands a majority and needs the MHP's support to pass legislation. At the moment, the alliance between AKP and MHP remains strong, but keeping this partnership may limit Erdoğan's room for manoeuvre in both domestic politics and foreign policy. To promote his agenda, Erdoğan may choose to circumvent the parliament on issues where he lacks the support of the majority. All in all, with Erdoğan's increasing control over the state apparatus, the Turkish political system continues to evolve into a hegemonic-authoritarian regime.

The local elections in March 2019 served as Erdoğan's first real challenge after the presidential elections. . Despite rifts in the coalition, the AKP and the MHP contested the local elections again as an alliance in many provinces and districts across the country. In response, the CHP and the IYi Party also renewed their electoral alliance in 22 metropolitan municipalities, 27 provinces, and many other districts. The HDP, on the other hand, decided not to nominate 
any candidates in major provinces to offer its implicit support for the main opposition party that was in a better position to defeat the candidates from the AKP-MHP alliance in these areas. Thus, the opposition appears to have adjusted to the new system by mobilizing their voters in tandem to defeat the candidates from the ruling alliance. Meanwhile, Erdoğan's strategy of mobilizing his own base with a divisive discourse, which had worked with much efficiency until now, backfired in the 2019 local elections as opposition voters united behind their candidates. Against the backdrop of an economic downturn that raised unemployment and inflation rates, several municipality governments from AKP and MHP switched to the opposition, including İstanbul and Ankara that has been ruled by politicians from the Islamist tradition since 1994. In a dramatic turn of events, mayors from the main opposition CHP now control five out of six of Turkey's most populous provinces. These municipality governments, with their sizable budgets, constituted the main financial resource for Erdogan and his party that distributed local funds in a partisan way. Their loss would not only allow the CHP to appeal directly to voters in these provinces but also diminish Erdoğan's ability to award his cronies (Esen \& Gumuscu, 2018). While the new system ran the risk of accelerating Turkey's slide to hegemonic authoritarianism, the strength of the opposition as reflected in the local elections has retained the competitiveness of the regime for now. Although no general election is officially scheduled until 2023, Erdogan will face an uphill battle to maintain political stability if the negative economic climate continues.

\section{References}

Esen, B., \& Gumuscu, S. (2016). Rising competitive authoritarianism in Turkey. Third World Quarterly, 37(9), 1581-1606.

Esen, B., \& Gumuscu, S. (2018). Building a competitive authoritarian regime: StateBusiness relations in the AKP's Turkey. Journal of Balkan and near Eastern Studies, 20(4), 349-372.

Klimek, P., Jiménez, R., Hidalgo, M., Hinteregger, A., \& Thurner, S. (2018). Forensic analysis of Turkish elections in 2017-2018. PLOS ONE, 13(10), e0204975.

OSCE. (2018, June 24). International election observation mission Republic of Turkey. Early presidential and parliamentary elections. Retrieved from https://www.osce. org/odihr/elections/turkey/385671?download=true 